\title{
Poverty Alleviation by Education is A Kind of Awakening and Discovery: In Memory of the "Poverty Alleviation War" of a Retired Middle School Principal in Eastern China
}

\author{
Yuhan Hai \\ South-Central University for Nationalities, Wuhan 430074, Hubei, China
}

\begin{abstract}
The development of education to improve poverty in the region has become an essential direction of the world's poverty alleviation work. In the poverty alleviation by education work in China, educators who are on the front line of poverty are determined by education and nurturing their wisdom, leading countless children from families out of poverty and toward hope. In 2016, Liqun Chen, the principal who retired from a prestigious high school in eastern China loving the Miao Townships, insisted on combining poverty alleviation with supporting aspirations, using the love and responsibility of a "teacher" to inject new spirit into basic education in ethnic areas. He ignited dreams and hopes for children in frontier regions. This article elaborates on Liqun Chen's help and aspirations in Taijiang County from the perspectives of students, teachers, and regions.
\end{abstract}

Science Insights Education Frontiers 2021; 8(2):1097-1107.

Doi: 10.15354/sief.21.rp001

How to Cite: Hai, Y. (2021). Poverty alleviation by education is a kind of awakening and discovery: In memory of the "Poverty alleviation war" of a retired middle school principal in eastern China. Science Insights Education Frontiers, 8(2):1097-1107.

Keywords: Poverty Alleviation by Education, Liqun Chen, High School Principal, Voluntary Education Assistance 


\section{Introduction}

I

$\mathrm{N}$ targeted poverty alleviation, aspirations are the cornerstone, academic support is the path, and poverty alleviation has a sustainable endogenous motivation for poverty alleviation (Wang, 2019). Studies have shown that mobilizing the internal poverty alleviation motivation of the target can accelerate the speed of poverty alleviation and effectively prevent the risk of returning to poverty (Tuo, 2003). The same is valid for education assistance. Education is not only to teach students the skills of learning and work but, more importantly, to eliminate the spiritual poverty of students. And then guide students, teachers, and the general populations in poverty-stricken areas to correctly understand the relationship between education and poverty alleviation, and attach importance to self-education and family education.

Taijiang County is located in the eastern part of the Yunnan-Guizhou Plateau. Known as "the first Miao County in the world," it is a national-level poverty-stricken county. The G60 highway and 320 expresses pass through the county, and no train is there to this day. There is currently no traffic light in the city, and $98 \%$ of the population is the Miao minority (Taijiang County Government, 2017). As the only public high school in the county, Taijiang Nationality Middle School has more than 1,200 poor households among more than 3,000 students.

In the fight against poverty, Taijiang County has become a key county for national assistance, and it has developed counterpart assistance cooperation with Hangzhou City. In August 2016, Liqun Chen retired from Hangzhou Xuejun High School, a key national high school, as the principal. Under the coordination and invitation of the support team, he declined high-paying invitations from many school-running institutions and went to remote mountainous areas in southeastern Guizhou to support education freely. He became the principal of the only private high school in Taijiang County, Guizhou Province, namely Taijiang National Middle School in Guizhou Province. After entering the school, Liqu Chen extended the original teaching time, repeatedly using actions to practice the persistent belief of "training children in poverty-stricken areas

Correspondence to: Yuhan Hai, School of Literature, Journalism \& Communication, South-Central University for Nationalities, Wuhan, 430074, Hubei, China.Email:496161725@qq.com

Conflict of Interests: None.

(C) 2021 Insights Publisher. All rights reserved.

Creative Commons Non Commercial CC BY-NC: This article is distributed under the terms of the Crea-

tive Commons Attribution-NonCommercial 4.0 License (http://www.creativecommons.org/licenses/by-

$\mathrm{nc} / 4.0 /$ ) which permits non-commercial use, reproduction and distribution of the work without further permission provided the original work is attributed by the Insights Publisher. 
well to cut off the intergenerational transmission of poverty." His efforts led the quality of Taijiang National Middle School education to become the first in the prefecture. They helped more than 2,200 poor Miao children in Taijiang County get out of the mountains, thus wholly changing their lives.

Liqun Chen's deeds of voluntary education assistance have been widely praised. Liqun Chen has been awarded the first China Education Reform and Innovation Outstanding Principal Award, Zhejiang Chuncan Award, the first Hangzhou Top Ten Teachers Touching Hangzhou, Zhejiang Education Top Ten Annual News Figures in 2017, and Guizhou Provincial Advanced Individual in Poverty Alleviation. In 2019, he was awarded the title of "Model of the Times" by the Central Propaganda Department. He believes that he is "a model of teaching and educating people in the practice of giving priority to the development of education and building a strong education country, and an outstanding representative of the "four haves" teachers in the new era." (Xinhua News Agency, 2019).

\title{
Poverty Alleviation First Supports the Aspiration and Helps the Students to Establish Their Aspirations
}

\begin{abstract}
"The most important thing for educators is to transform strict external requirements into powerful motivation for students to spontaneously and internally drive. Without this, it will not be an education." This is what Liqun Chen wrote in the book "My Educational Propositions" (Chen, 2015). As an educator with the aura of "all Chinese principals," Liqun Chen has dedicated himself to his teaching career for more than 30 years. He insisted on integrating grand aspiration education into teaching, creating a solid aspirational education atmosphere, guiding students to establish lofty aspirations, and laying a solid foundation for students to grow into talents.
\end{abstract}

\section{Change the Idea of "Education is Useless"}

In China, where compulsory education continues to be popularized, the argument that "education is useless" has gradually disappeared. However, with the continuous advancement of the urban process, a large number of rural laborers flock to the cities. Compared with the temporarily unprofitable educational investment, more parents or students choose to give up education and go out to work to help their families escape poverty. Under this circumstance, a new argument of "reading is useless" has emerged, and more and more rural children and parents believe that they can make money even if they go out to work without studying (Qin \& Wang, 2020). This idea is also deeply ingrained in the hearts of the students of Taijiang National Middle School.

After a monthly exam, Liqun Chen received an anonymous letter from the student stating that at least 500 students cheated by their mobile phones during the 12thgrader monthly exam. The student said that some students go to high school to get a diploma and find a wife. "There are too many students who don't want to learn." The student at the end of the letter wrote: "My outlook on life and values is to start a busi- 
ness and start a company of my own, with a net worth of tens of billions, drive a luxury car, live in a villa, be keen on public welfare, and pass on the love. Education is just a piece of paper. I won't go to school next semester. I want to go out to earn money."

Faced with such a situation, Liqun Chen gradually realized that learning is far less important than starting a family in a village where there has not been a college student for more than ten years. So, he thought of many ways. In the big playground, he read to everyone the heart-wrenching anonymous letter that 500 students cheated by their mobile phones in the exam. He warned everyone that if they did not study, they would be like their parents and become "the backup of migrant workers." Only by learning can the next generation get rid of this vicious circle and complete the leap from "illiterate and semi-illiterate family" to "knowledge family" (Yin, 2020).

\section{Strict Management and Cultivate Good Study Habits}

Learning habit is a unique behavioral way of learning formed through repeated practice in the student's time. Good study habits can improve learning efficiency and reduce learning resistance. Bad learning habits are harmful or affect personal learning (Rabia et al., 2017).

Liqun Chen decided to start with learning habits. He first created the "Quiet Learning Month" throughout the school. At the school-wide conference, I will teach teachers and students the principle of "being calm when there is a big event." A homeroom teacher meeting was held, and it was proposed that discussions in the classroom during evening self-study were not allowed. Every class must be checked and evaluated every day. He went to the teaching building to inspect the classrooms every morning, noon, and night.

In the second month, Liqun Chen announced that the whole school had entered the "Autonomous Learning Month." He asked the students to record the previous month's exam results, set a goal for the next month's exam, and sprint to make breakthroughs. The school-wide statistical appraisal was conducted on the total achievement scores of each class.

Considering the labor output of rural families in Taijiang County that led to a large number of left-behind children and disorderly spared time, Liqun Chen decided to implement closed boarding management at school. That is, every week, except Saturday night, there is no evening self-study, and other times 6:30-10:20 evening self-study. All students wear school uniforms at school. Students hand in their mobile phones to the school for safekeeping and return them when they go home on weekends.

His ensuing thunder tactics hit the school directly. A few months later, the style of the school has changed. "More than 3,000 people and over 50 classrooms in the school had become quiet and orderly within only two months" (Li et al., 2019).

\section{Rooted in Miao's Culture to Establish “Ambition” For- est}


The tree is the totem of the Miao nationality. Compatriots of the Miao nationality have the custom of "a tree for life and death": plant a tree when they are born, and cut down the tree when they die, and use it as their own coffin. Liqun Chen started from the life relationship between the Miao people and the trees, enriching the new connotation of "ambition."

Since Liqun Chen became the principal of Taijiang National Middle School, teachers and students have had one more festival: "12.9 Inspirational Festival". On this day of each year, the 12th-grade teachers and students have to plant an "ambition tree" on campus based on the class. There is also a bottle buried under the tree; inside it is the college entrance examination aspirations and life ideals of the whole course of teachers and students. Not far from the gate of Taijiang National Middle School, you can see the "Ambition Forest" planted by the teachers and students of the school. Although they are still seedlings, they are already lush.

Through class meetings, adult ceremonies, flag-raising speeches, recitation competitions, study tours, club activities, and reading activities, Liqun Chen strengthened and stimulated the understanding and thinking of "ambition" among teachers and students. It is hoped that the teachers and students of the Miao nationality can cultivate "lofty ambition, high aspiration, and elegant inclination" to become the spiritual arm that leads and accompanies life. (Pang \& Lee, 2019)

\section{Practice Education and Awaken Teachers' Educa- tional Potential}

Poverty alleviation is a job aimed at people. On the one hand, it is necessary to put people first, implement policies according to households, and "target therapies." On the other hand, we must rely on a solid poverty alleviation work team to make the poverty alleviation work detailed and practical. The successful implementation of poverty alleviation by education is also inseparable from the hard work of a group of teachers who have been committed to education in impoverished areas for many years. As Liqun Chen once mentioned in a report, "All assistance is always temporary, and all educational assistance always ends. The key is to enhance the output function of the sustainable development of education in poverty-stricken areas. The most important thing for schools is Teachers must awaken their sense of responsibility and stimulate their educational potential." (Zhu, 2019).

\section{Rectify the Teaching Style and Improve the Overall Quality of Teaching}

The teaching style is the attitude and morality of teachers in teaching and educating people. Teachers must not only create and disseminate knowledge but also use their good moral qualities to influence students to guide and nurture students in scientific knowledge, thoughts, emotions, and behavioral methods (Yang \& Gong, 2004). 
When he first arrived at Taijiang National Middle School, Liqun Chen was shocked by the school's chaotic teaching order: it has become common for some teachers to arrive late and leave early. Some teachers stood in the hallway and chatted during class. Some teachers went to eat breakfast after clocking in for early reading class. Some proctors slipped to the office halfway through. In this learning atmosphere, students slept in class and wandered in groups in the town after school. It was common to smoke, puppy love, and play games. After that, Liqun Chen organized all teachers in the school to let teachers themselves take part in a monthly exam prepared for 12thgrade students. The teacher dealt with it perfunctorily, whispering to each other and copying other teachers' answer sheets. This time, Liqun Chen was invigilated by Liqun Chen himself, but some teachers failed the exam.

Therefore, Liqun Chen surveyed the situation of teachers in the whole school, and the results were surprising. As the only public high school in the county, Taijiang Nationality Middle School had 178 full-time teachers; 59 were from junior high schools in various towns in the county. Therefore, the low level of teachers' overall professionalism is evident.

To establish a good teaching atmosphere and improve the quality of the teaching staff as soon as possible, more than a dozen systems and regulations were issued within two months. The whole school began closed management, with early reading and late self-study in each classroom for checking and appraisal and strict control of teachers' attendance. Liqun Chen successfully invited 68 teachers from Hangzhou to support teaching in Taijiang to carry out teacher training projects. Each grade and teaching group started to listen to and evaluate each other. At the same time, they took advantage of the resources of Kaili No.1 High School of Guizhou Province, a famous school in Southwestern Guizhou, and invited their teachers in to "same class but different structure" with teachers from Taijiang National Middle School. That is to say, for the same course, the teachers of the two schools can each give a lecture and then listen to and evaluate each other. Every Saturday afternoon, Kaili No.1 High School of Guizhou Province sent nine young teachers to the school to give lectures. Lecture subjects covered nine school subjects. Each topic also sent a teacher specializing in listening and commenting - one grade a week, from the junior students to the senior students. Liqun Chen also promoted the establishment of a "going out" training system. Within three years, eight batches of 134 teachers went to key middle schools in Hangzhou to accept on-job training (Huang \& Wang, 2019).

\section{Strengthen the Training of Famous Teachers and Cul- tivate a Team of Teachers in Taijiang County Who are "Not to Take Away"}

"Cultivating a team of backbone teachers that can't be taken away is the key to the school's sustainable development." Under the promotion of Liqun Chen, Taijiang Nationality Middle School launched the "Young Teacher Training Action Plan." For 
young teachers who have been working for less than three years, key teachers who have been working for 3 to 8 years, and senior teachers who have been working for more than eight years, different training goals have been set up.

Because of the low salary, several teachers leave the school every year. To solve teacher treatment and let teachers in Taijiang County work at ease, Liqun Chen traveled to the county to obtain resources for teachers. In April 2018, the Hangzhou Municipal Government helped Taijiang 10 million yuan, and the county allocated 3.2 million yuan to Taijiang National Middle School. Liqun Chen used it to reward teachers. He also took out the special government allowance of the State Council and the Hangzhou Outstanding Talent Award of more than 200,000 CNY and set up a "teaching scholarship" to award nine teachers each year with 5,000 CNY each.

Besides, Liqun Chen took the initiative to take over many "extra things." $\mathrm{He}$ began to train principals and teachers throughout the county, the entire prefecture, and even the province and gave compulsory lessons to some schools in Taijiang County or Southwest Guizhou. He served as the instructor of the famous principal's studio of Fangzhao Town Elementary School. Voluntarily give reports and give more than 60 lectures, and more than 10,000 principals and teachers have been trained.

Liqun Chen's spirit of "establishing education and cultivating people with morality" touched everyone. More and more teachers choose to stay in Taijiang County to continue teaching. At the same time, it also attracts groups of young and outstanding teachers to come to support teaching and make silent contributions to Taijiang in the deep mountains. Not only that, but many students admitted to the university also said that after returning from school, they must contribute their own strength to their hometown and use practical actions to encourage more students in poor areas to study hard (Li, 2020).

\section{Levering Low-Level Thoughts, Restarting Respect for Teachers and Education}

"Education is firstly the growth of the spirit, and secondly it becomes part of the scientific acquisition." (Jaspers, 1999). Regardless of students, teachers, and parents, Liqun Chen attaches great importance to the power of "spiritual awakening" and "spiritual education."

Before Liqun Chen arrived, Taijiang County, a village with more than 2,200, did not get its first college student until 2014. Some village children set out to school before dawn. One was that they were far away, and the other was that they would be brought back once neighbors found them. Because the villagers generally believed that "our children do not read, their children go to school, and they will bully us when they come back." Some parents went to school on weekends to give their children daily necessities and brought homemade tobacco. In the eyes of parents, "to smoke and drink is a sign of man." For learning, locals seemed to have no hope of this school. The school organized a parent-teacher meeting, and very few parents were present. There were more teachers than parents at the meeting. During the college entrance examination, 
few parents waited in twos and threes at the school gate, and it seemed that few people paid attention to the college entrance examination.

Education is a permanent solution to stop the intergenerational transmission of poverty. How to restore and create a good folk tradition of respecting teachers, cultivating and studying in underdeveloped areas has been a question that Liqun Chen has been thinking about since entering Taijiang County.

Therefore, Liqun Chen started from the masses, publicized the meaning of education, awakened the motivation of the groups to change the status quo, moved the bottom of society, and removed the "big mountains" that lie in people's hearts.

On the one hand, Liqun Chen proposed to rebuild Wenchang Palace and Lotus Academy. Wenchang Palace and Lotus Academy are located on the east hillside of the county seat and were built during the Guangxu dynasty. At that time, Qingzhi Zhou, who was also known as the Tongzhi ${ }^{\underline{I}}$ of Taigong Hall ${ }^{\underline{2}}$, was the advocator of these two buildings; under his persuasion, the children of the Miao family began to study, and the trend of respecting teachers and teachings became more and more popular. Today, the courtyard is empty, and the academy is withered. Due to disrepair, the roof of the Wenchang Palace is tilted 1.5 meters southward. Under Liqun Chen's initiative, the county government has organized to renovate Wenchang Palace and Lotus Academy. Liqun Chen bought a statue of Confucius at his own expense, more than 80,000 CNY, and placed it in the academy. He suggested that the county set up a Taijiang library outside the academy to form a good atmosphere of reading and re-education.

On the other hand, Liqun Chen organized school teachers into the village to preach so that the people fully realized the significance of education for changing poverty. Under the coordination of the local government, Liqun Chen personally trained cadres in the village. The content includes education and poverty alleviation, respect for teachers and education, and family education. He said that only by "moving up the lowest level of society" and forming a tradition of respecting teachers and teaching people in Taijiang leap the true sense.

With the strong support of the county government, every year after the college entrance examination results came out; Liqun Chen organized school teachers to come to the village to congratulate them. He took the teacher to the home of the students who had passed the exam to deliver the happy news, set off firecrackers, and posted the admission list on the most conspicuous wall of the stockade. He wanted to let the whole village see it and "fire up the education atmosphere." Vigorously promote the typical deeds of "getting a child out of poverty, lifting a family out of poverty, and driving a stockade forward" to inspire villagers to attach importance to education.

Besides, parents who emphasize education will be rewarded. More villages have held commendation meetings in the past two years, and the bonuses are getting higher (Huang \& Wang, 2019).

\section{All Forces Gather to Help Students Realize Their Col- lege Dreams}


Southeast Guizhou is the main battlefield for the nation's poverty alleviation. Taijiang County has been a state-level poor county until 2019. In 2016, the annual fiscal revenue of Taijiang County was 270 million CNY, but the budgetary expenditure was 1.5 billion CNY, mainly relying on central fiscal transfer payments (time, 2019). As the only public high school in the county, Taijiang Nationality Middle School has deplorable school conditions.

For all students to study at school with peace of mind, teachers teach at school with peace of mind. Thanks to Liqun Chen's efforts, more and more locals attach importance to education, and more and more foreigners pay attention to education in Taijiang. Under various assistance policies, the phenomenon of dropping out of school due to family difficulties has been eliminated, and the school infrastructure conditions have also been improved. The number of student canteens increased from one to three, and a separate teaching staff canteen was opened. Strengthen logistics management, invest a certain amount of money, improve the quality of food, and strictly manage sanitation. The construction of the student dormitory, which had been delayed again and again, was quickly completed, and each dormitory had its bathroom. Some companies took the initiative to contact Liqun Chen to donate money to students to solve college tuition for needy students in Taijiang Nationality Middle School.

Since he came to Taijiang County in 2016 to support teaching, Liqun Chen's teaching time has been postponed again and again, from one year to four years. At the same time, Taijiang Nationality Middle School's undergraduate admission rate for the college entrance examination rushed from the end of the state to the first in the state. Among the 1,047 candidates for the college entrance examination in 2020, 829 have reached the undergraduate level, of which 270 have gone to the first level, and the undergraduate online rate reached $79.2 \%$. Only four years ago, Taijiang Nationality Middle School's undergraduate entrance examination rate was only $10 \%$. More than 2,200 students from the school have been admitted to undergraduates in the past four years and have stepped out of the barren mountain (Yin, 2020).

In August 2020, Liqun Chen stepped down as the principal of Taijiang National Middle School. Before he left, the people of Taijiang gave him a new identity-the lifelong honorary principal of Taijiang Nationality Middle School. Today, 63-year-old Liqun Chen is still traveling back and forth between Hangzhou and Taijiang. He said that he would frequently travel between Hangzhou and Guizhou to voluntarily give lectures to principals here for a long time in the future.

During Liqun Chen's teaching support process, he always regards cultivating good habits and cultivating the spirit of struggle as an essential starting point and goal of poverty alleviation by education (Ju et al., 2020). For poverty-stricken areas represented by Taijiang County set up good educational ambitions, create an intense atmosphere of ideals and virtues, and awaken the hearts of the low-level people to settle for poverty. This may be more important than the simple input of material, human and educational resources. 
Hai. "Poverty Alleviation War" of a Retired Middle School Principal.

\section{Notes}

1. Tongzhi, the official name of the Ming and Qing Dynasties, was the deputy of the prefect.

2. Taigong Hall is today's Taijiang County, Guizhou. In the eleventh year of Emperor Yongzheng in the Qing Dynasty (1733), the Taigong Hall was established, and it was renamed Taigong County in 1913 and Taijiang County in 1942.

\section{References}

Chen, L. (2015) My educational proposition. Shanghai: East China Normal University Press. ISBN: 978756575121. [Chinese]

Huang, X., \& Wang, J. (2019). Liqun Chen went to Miao Township, Guizhou Province, to support education, changing Taijiang National Middle School from a "bad school" to a "prestigious school"-this "Ambition Forest" is already full of luxuriant eyes. People's Daily, 09-10. [Chinese] http://dangjian.people.com.cn/n1/2019/0910/ c117092-31345861.html

Jaspers, K. T. (1999) Was ist Erziehung?. Piper Verlag GmbH ISBN-13: 978-349-211-513-1.

Ju, H., Yang, Y., \& Yang, P. (2020). "Poverty alleviation by education, it is important to stimulate the inner potential of teachers and students"-Interview with Liqun Chen, a model for teaching and educating people in China in 2019, and Liqun Chen, head of the Nationality Middle School in Taijiang County, Guizhou Province. Ethnic Education of China, 27(4):14-17. [Chinese] DOI: https://doi.org/10.16855/j.cnki.zgmzjy.2020. $\underline{04.008}$

Li, Y. (2020). From "bad school" to "prestigious school" in Taijiang National Middle School in Southeast Guizhou in 4 years. Guizhou Daily, 09-09. [Chinese] http://www.gywb.cn/system/2020/09/09/030 699606.shtml?from=groupmessage

Li, Y., Li, J., \& Yu, W. (2019). At a young age, a master like a father-Liqun Chen, a teacher in Zhejiang, and the "famous principal's father" in Taijiang, Guizhou. Xinhua Network. [Chinese] [2019-05-11]//[2021-02-22] https://baijiahao.baidu.com/s?id=163320743 $9784076343 \& \mathrm{wfr}=$ spider $\&$ for $=\mathrm{pc}$

Pang, B., \& Li, Z. (2019). "Model of the times" Liqun Chen: Give children a pair of wings. Guizhou Today, 21(35):46-47. [Chinese] DOI: https://www.cnki.com.cn/Article/CJFDTotal -GZDD201935030.htm

People's Government of Taijiang County. (2017) Overview of Taijiang. /[2021-02-20] [Chinese] http://www.gztaijiang.gov.cn/zitj/tiji/[201703-06]/

Qin, Y., \& Wang, Y. (2020). The reinterpretation and deciphering logic of the theory of "education is useless" in the new era. Research in Educational Development, 2020(20):1-6+45. [Chinese] DOI: https://doi.org/10.14121/j.cnki.1008$\underline{3855.2020 .20 .003}$

Rabia, M., Mubarak, N., Tallat, H., \& Nasir, W. (2017). A study on study habits and academic performance of students. International Journal of Asian Social Science, 7(10):891897. DOI: https://doi.org/10.18488/journal.1.2017.710. $\underline{891.897}$

Shi, X. (2018). Poverty alleviation battle of a retired principal-The story of teaching support by Liqun Chen, the head of the Taijiang 
Hai. "Poverty Alleviation War" of a Retired Middle School Principal.

National Middle School, Guizhou Province. China Education News, 11-26 (01 edition). [Chinese]

https://baijiahao.baidu.com/s?id=161818567 0994171624\&wfr=spider\&for $=$ pc

The Central Propaganda Department awarded Liqun Chen the title of "Model of the Times." (2019, September 9). [Chinese] Retrieved February 3, 2021, from

https://baijiahao.baidu.com/s?id=164418536 $6498964385 \&$ wfr $=$ spider $\&$ for $=p c$

Tuo, P. (2003). Poverty alleviation and ambition promotion. Seeking Truth, 10(5):52. [Chinese]

https://www.cnki.com.cn/Article/CJFDTotal -QUSI200305023.htm

Wang, Y. (2019). Coordinating the relationship between helping will and helping wisdom in precision poverty alleviation. People's Tribune, 26(20):66-67. [Chinese]
https://www.cnki.com.cn/Article/CJFDTotal -RMLT201920019.htm

Yang, W., \& Gong, P. (2004). On the construction of learning style and teaching style. Journal of Wenzhou University (Social Science Edition), 7(1):31-33+38. [Chinese] DOI: https://doi.org/10.3875/j.issn.16743555.2004.01.008

Yin, H. (2020). The principal of the eastern part is in the western region: "Hot the education atmosphere." China Youth Daily, 10-14. [Chinese] https://baijiahao.baidu.com/s?id=168052352 $\underline{8658139135 \& w f r=\text { spider \&for }=p c}$

Zhu, L. (2019) Love and responsibility, whatever happens: Liqun Chen, Principal of Taijiang National Middle School, Guizhou Province. China Education News Network, 09-11. [Chinese]

http://www.wenming.cn/sdkm/chelq/xjsj/20 1909/t20190911_5251052.shtml 